\title{
Genetic mutations in the treatment of anaplastic thyroid cancer: a systematic review
}

\author{
Anna Guerra', Vincenzo Di Crescenzo ${ }^{1}$, Alfredo Garzi ${ }^{1}$, Mariapia Cinelli², Chiara Carlomagno ${ }^{3}$, \\ Massimo Tonacchera ${ }^{4}$, Pio Zeppa ${ }^{1}$, Mario Vitale ${ }^{1 *}$ \\ From 26th National Congress of the Italian Society of Geriatric Surgery \\ Naples, Italy. 19-22 June 2013
}

\begin{abstract}
Background: Anaplastic thyroid cancer (ATC) is a rare, lethal disease associated with a median survival of 6 months despite the best multidisciplinary care. Surgical resection is not curative in ATC patients, being often a palliative procedure. Multidisciplinary care may include surgery, loco-regional radiotherapy, and systemic therapy. Besides conventional chemotherapy, multi kinase-targeted inhibitors are emerging as novel therapeutic tools. The numerous molecular alteration detected in ATC are targets for these inhibitors. The aim of this review is to determine the prevalence of the major genetic alterations occurring in ATC and place the results in the context of the emerging kinase-targeted therapies.
\end{abstract}

Methods: The study is based on published PubMed studies addressing the prevalence of BRAF, RAS, PTEN, PI3KCA and TP53 mutations and RET rearrangements in ATC.

Results: 21 articles dealing with 652 genetic analyses of the selected genes were used. The overall prevalence determined were the following: RET/PTC, 4\%; BRAF, 23\%; RAS, 60\%; PTEN, 16\%; PI3KCA, 24\%; TP53, 48\%. Genetic alterations are sometimes overlapping.

Conclusions: Mutations of BRAF, PTEN and PI3KCA genes are common in ATC, with RAS and TP53 being the most frequent. Given ATC genetic complexity, effective therapies may benefit from individualized therapeutic regimens in a multidisciplinary approach.

\section{Introduction}

Thyroid cancer is the most prevalent endocrine malignancy accounting for $1 \%$ of cancers worldwide. More than $95 \%$ of thyroid cancer are well differentiated tumors that respond to surgery followed by radioactive iodine (RAI) therapy and thyroid hormone suppression. Although disease recurrence occurs in approximately $30 \%$ of cases, nowadays thyroid cancers have a very favorable outcome. The clinical appearance of thyroid cancer is that of a nodules, some time representing a challenging diagnostic dilemma with thyroid or unusual extrathyroidal masses [1,2]. The use of effective diagnostic tools such as ultrasound (US) and fine-needle cytology (FNC) [3-5] has increased the detection of small and well

\footnotetext{
* Correspondence: mavitale@unisa.it

${ }^{1}$ Medicine and Surgery, University of Salerno, Salerno, Italy

Full list of author information is available at the end of the article
}

differentiated tumors in their early stages. Moreover, the application of molecular techniques to FNC has dramatically increased its sensitivity [3,4,6-9]. An effective FNC diagnosis avoids useless diagnostic surgery or provides indications for the proper surgical treatment, when needed $[10,11]$. Poorly differentiated subtypes, including anaplastic thyroid cancer (ATC), are resistant to RAI and conventional chemotherapy. ATC accounts for about $1 \%$ of thyroid cancer and is typical of old age. When feasible, surgery must aim at a radical intent; however, surgical resection is not curative in ATC patients, being often a palliative procedure $[10,11]$. Therefore, an early and accurate diagnosis is mandatory in case of ATC which does not require surgical treatment, and even more in elderly patients, for whom surgery is generally more burdensome, complex and expensive than younger patients $[10,11]$. Standard chemotherapies have systemic toxicities and limited
C Biomed Central

C 2013 Guerra et al.; licensee BioMed Central Ltd. This is an open access article distributed under the terms of the Creative Commons Attribution License (http://creativecommons.org/licenses/by/2.0), which permits unrestricted use, distribution, and reproduction in any medium, provided the original work is properly cited. 
efficacy in the case of ATC as well as of other more common solid tumors [12-14]. Alternative strategies such as immunotherapy are under investigation, but still far from clinical practice [15]. At present, genetic-based targeted therapy is the most promising curative strategy. Hallmarks of all cancers are self-sufficiency in growth signals and evasion of programmed cell death. Tyrosine kinase receptors/ RAS/RAF/MAPK and RAS/PI3K/Akt/mTOR are the major signaling pathways involved in cell proliferation, protein synthesis and cell survival. Thyroid cancer is characterized by several genetic alterations along these two pathways, including rearrangements of the RET (rearranged during transfection; $R E T / P T C$ ) tyrosine receptor kinase, activating point mutations in the BRAF serine/ threonine kinase, in the $R A S$ proto-oncogenes, in the catalytic subunit of the phosphatidyl-inositol 3-Kinase (PI3KCA), or inactivating mutations in the tumor suppressors phosphatase and tensin homolog (PTEN) and TP53 (Table 1). ATC is the product of the accumulation of genetic alterations due to genetic instability and external factors such as food or environmental factors, including ionizing radiations and oxidative stress. Oxidative stress has been implicated in the mechanism of cancer, diabetes, cardiovascular and other diseases [16,17]. Oxidant molecules are generated by stress agents such chemicals, drugs, pollutants, and high-caloric diets [18]. Conversely, there is no hint of a remodeling of the $\mathrm{Ca}^{2+}$ toolkit, that has been observed in other malignancies, including renal cellular carcinoma [19-21], and prostate cancer [22], and has been put forward as alternative target for selective molecular therapies [14]. The last decade has seen advances in the understanding of the molecular basis of thyroid cancer, leading to the application of new pharmacological treatments with inhibitors of kinases [23-25]. These drugs are multi-target agents with inhibitory activity of receptors involved in the angiogenesis or inhibitors of kinases involved in thyroid cancer development. The BRAF inhibitor vemurafenib (PLX4032) improves survival among patients with metastatic melanoma, and suppresses growth of BRAF-mutated human ATC in a mouse model [26]. The beneficial effect of BRAF inhibition in ATC with activating BRAF mutations has been recently reported [27].

\section{Table 1 Gene mutations in ATC}

\begin{tabular}{|c|c|c|}
\hline Gene & Mutation & Signaling involvement \\
\hline RET & Recombination & MAPK activation \\
\hline BRAF & Single point mutation & MAPK activation \\
\hline $\begin{array}{l}H-, N-, K- \\
\quad R A S\end{array}$ & Single point mutation & $\begin{array}{c}\text { MAPK, PI3K/Akt/mTOR } \\
\text { activation }\end{array}$ \\
\hline PTEN & $\begin{array}{l}\text { Single point mutation/ } \\
\text { deletion }\end{array}$ & $\mathrm{PI} \mid 3 \mathrm{~K} / \mathrm{Akt} / \mathrm{mTOR}$ inactivation \\
\hline PIBKCA & Single point mutation & $\mathrm{PI3K}$ Akt/mTO activation \\
\hline TP53 & Single point mutation & P53 pathway inactivation \\
\hline
\end{tabular}

Other pharmacological compounds inhibit RET and RET/ PTC (sorafenib, sunitinib, vandetanib) or the mammalian target of rapamycin (mTOR), a component of the PI3K/ Akt signaling pathway (everolimus). Hence, the knowledge of the tumor mutation status is needed for optimizing and tailoring the treatment with kinase inhibitors. The intent of this systematic review is to determine the prevalence of the major genetic alterations occurring in ATC.

\section{Materials and methods}

A meta-analysis was performed by searching the MEDLINE database (National Library of Medicine, Bethesda, MD) using the terms "BRAF", "RAS", "PTEN", "PI3KCA", "TP53", "RET/PTC" or "BRAF," associated with the terms "anaplastic thyroid cancer" or "undifferentiated thyroid cancer". Studies were included only when the sample was $\geq 4$. Studies were selected on the basis of the detection of molecular alterations by genetic analysis. Studies based only on molecular detection by immunohistochemistry were excluded. Only data about different genes were included from studies by the same authors. Studies on poorly differentiated thyroid cancers and well differentiated thyroid cancers were also excluded.

\section{Results}

The literature search strategy retrieved 104 articles from PubMeD. Twenty-one studies met the inclusion criteria and were considered for further analysis. These studies were published between 1993 and 2010, and included 652 cases of ATC. All studies were retrospective, using stored formalin-fixed paraffin-embedded samples or frozen surgical specimens. The method used for determining the presence of single point mutations was direct sequencing of DNA after polymerase-chain reaction (PCR) amplification, PCR and fluorescence melting curve analysis and DNA-mutant allele-specific amplification (DNA-MASA). The methods used to determine $R E T$ rearrangements were PCR alone followed by direct sequencing or PCR followed by internal probe binding (Southern blot on PCR products). BRAF $F^{V 600 E}$ was the only $B R A F$ mutation considered by the 7 studies analyzed. The mutation ranged $0 \%-50 \%$ in 21 out of 89 tumors (Table 2). The mean prevalence was $23 \%$. Mutations in the three RAS isoforms ranged $8 \%-60 \%$ in 33 out of 162 ATCs (mean 60\%). Not all the three major RET rearrangements were considered in all studies. Tumors were tested for the presence of RET/PTC-1 and -3 in two studies and RET/ $P T C-1,-2$, and -3 in one study. Rearrangements were rare, being detected in $4 \%$ of ATCs, in the range $0 \%-6 \%$ in 3 out of 81 tumors. Inactivating mutations of PTEN were detected in $16 \%$ of 107 ATCs, while activating mutations of PI3KCA in $23 \%$ of 70 ATCs in the range 12\%-58\% (Table 3). Inactivating mutations of TP53 were identified in $48 \%$ of 25 tumors, in the range $10 \%-86 \%$. 
Table 2 Prevalence of mutations in the MAPK pathway in ATC

\begin{tabular}{|c|c|c|c|}
\hline Mutation & $\begin{array}{c}\text { Positive/ total } \\
\text { cases }\end{array}$ & $\begin{array}{c}\text { Prevalence } \\
\text { (\%) }\end{array}$ & Reference \\
\hline \multirow[t]{7}{*}{$B R A F^{V 600 E}$} & $0 / 7$ & 0 & [51] \\
\hline & $2 / 6$ & 33 & {$[52]$} \\
\hline & $3 / 29$ & 10 & [53] \\
\hline & $2 / 10$ & 20 & [54] \\
\hline & $8 / 16$ & 50 & {$[55]$} \\
\hline & $0 / 4$ & 0 & {$[56]$} \\
\hline & $6 / 17$ & 35 & {$[57]$} \\
\hline Overall $B R A F^{V 600 E}$ & $21 / 89$ & 23 & \\
\hline \multirow[t]{7}{*}{ RAS } & $4 / 50$ & 8 & {$[44]$} \\
\hline & $2 / 18$ & 11 & [58] \\
\hline & $1 / 5$ & 20 & [59] \\
\hline & $4 / 18$ & 23 & [43] \\
\hline & $15 / 29$ & 55 & {$[60]$} \\
\hline & $4 / 50$ & 8 & {$[61]$} \\
\hline & $3 / 5$ & 60 & {$[62]$} \\
\hline $\begin{array}{l}\text { Overall RAS } \\
\text { mutations }\end{array}$ & $33 / 162$ & 20 & \\
\hline \multirow[t]{3}{*}{ RET/PTC } & $0 / 14$ & 0 & [63] \\
\hline & $3 / 51$ & 6 & {$[44]$} \\
\hline & $0 / 17$ & 0 & {$[64]$} \\
\hline Overall RET/PTC & $3 / 81$ & 4 & \\
\hline
\end{tabular}

Table 3 Prevalence of mutations not in the MAPK pathway in ATC

\begin{tabular}{cccc}
\hline Mutation & Positive/ total cases & Prevalence (\%) & Reference \\
\hline PTEN & $8 / 48$ & 17 & {$[44]$} \\
& $8 / 50$ & 16 & {$[61]$} \\
Overall PTEN & $1 / 9$ & 10 & {$[65]$} \\
\hline PI3KCA & $17 / 107$ & 16 & \\
\hline TP53 & $6 / 50$ & 12 & {$[44]$} \\
& $4 / 18$ & 22 & {$[58]$} \\
Overall PI3KCA & $29 / 50$ & 58 & {$[61]$} \\
\hline & $16 / 70$ & 23 & {$[66]$} \\
Overall TP53 & $45 / 188$ & 24 & \\
\hline
\end{tabular}

\section{Discussion}

The prognosis of differentiated thyroidal tumors is generally favorable mainly because there are different and effective tools in the early diagnosis and treatment of these tumors [28]. In fact, the use of US and FNC in the diagnosis of thyroid nodules usually leads to an early and accurate diagnosis of small and differentiated tumors, as well as less frequent thyroidal neoplasms $[3,5,6]$. In particular FNC, coupled with immunocytochemistry (ICC),
Table 4 Major pharmaceutical compounds in clinical development for the treatment of thyroid cancer

\begin{tabular}{lccccc}
\hline $\begin{array}{l}\text { Pharmaceutical } \\
\text { compound }\end{array}$ & VEGFRs & $\begin{array}{c}\text { RET/ } \\
\text { PTC }\end{array}$ & $\begin{array}{c}\text { BRAF PDFGR } \\
\text { mTORC1 }\end{array}$ \\
\hline Axitinib & + & & - & + & - \\
Cabozantinib & + - & & - & - & - \\
Lenvatinib & + & & - & + & - \\
Motesanib & + & & - & + & - \\
Pazopanib & + & & - & + & - \\
Sorafenib & + & + & + & + & - \\
Sunitinib & + & + & - & + & - \\
Vandetanib & + & + & - & - & - \\
Vemurafenib & - & - & + & - & - \\
Everolimus & - & - & - & - & + \\
\hline
\end{tabular}

flow cytometry (FC) and molecular techniques [3-6,29-31] has dramatically enhanced the sensitivity and the accuracy of preoperative diagnosis of thyroidal nodules $[3,5,29]$. The bad prognosis of advanced thyroid carcinoma, prompted researchers to evaluate the efficacy of new pharmaceutical compounds with enzymatic inhibitory properties (Table 4). The prevalence of RET/PTC rearrangements in ATC was much lower than in papillary thyroid cancer reported in most of the studies (4\% vs. $36 \%)[25,32]$. Noteworthy, benign thyroid nodules exhibiting RET/PTC rearrangements do not evolve in cancer $[33,34]$. This data suggest that this oncogene has a minor role in the progression from well-differentiated to undifferentiated thyroid cancer. It also indicate that tyrosine kinase inhibitors such as sorafenib, sunitinib, and vandetanib have little chance to function through the inhibition of this oncogene in ATC. The encouraging results obtained by these drugs in non RAI-responsive differentiated thyroid carcinomas in some clinical trials where the RET rearrangement was not evaluated, were more likely due to the effects on neo-angiogenesis [35]. The high prevalence of $B R A F^{V 600 E}$ mutation in ATC supports the hypothesis that many ATCs actually represent a progressive malignant degeneration of $B R A F$-mutated, well-differentiated thyroid carcinomas [36]. This gene is a pivotal component of the MAPK pathway and reduces the activity of $\mathrm{p} 21^{\mathrm{kip} 1}$ in thyroid tumors, stimulating the cell cycle machinery [37]. Vemurafenib (PLX4032), a BRAF selective kinase inhibitor and sorafenib, a multitarget inhibitor, find application in selected BRAFmutation positive melanomas [38]. Although clinical studies of BRAF inhibitors in advanced non RAI-responsive differentiated thyroid carcinomas have shown encouraging results with frequent early responses, in a relevant fraction of patients this effect was of limited duration, with frequent relapse or no response. In addition, intratumoral heterogeneity with respect to $B R A F$ mutation makes the evaluation of these clinical trials even more 
complex $[39,40]$. Poor results were obtained with sorafenib in ATC, although positive results reported with vemurafenib in one ATC with $B R A F^{V 600 E}$ mutation are worthy to be mentioned $[27,35]$. A relevant obstacle to the efficacy of treatments based on the inhibition of BRAF ${ }^{\mathrm{V} 600 \mathrm{E}}$ is the presence of activating mutations of RAS. This proto-oncogene is a small GTP binding protein located upstream RAF in the MAPK cascade. Activating mutations of this protein reactivate the MAPK pathway, making $B R A F^{V 600 E}$ inhibition inefficient [41]. The high prevalence of $R A S$ activating mutations in ATC $(60 \%)$ makes the inhibition of the MAPK pathway by kinase inhibitors a strategy whose success is unlikely. Moreover, papillary thyroid carcinoma and ATC exhibit concomitant $B R A F^{V 600 E}$ and $R A S$ mutations, although a rare occurrence [42-44]. In light of these considerations, the pharmacological inhibition of the MAPK pathway looks less promising than the inhibition of the PI3K/Akt/ mTOR pathway. This pathway is constitutively activated by inactivating mutations of PTEN and by activating mutations of PI3KCA. Both mutations are frequent in ATC (10\% and $24 \%$ respectively). Ongoing studies in cells, both in culture and in vivo, are investigating the anticancer effect of the novel allosteric Akt inhibitor, MK2206, in combination with several anticancer agents [45]. This agent selectively inhibits thyroid cancer cells harboring mutations that can activate the PI3K/Akt pathway $[46,47]$. An appealing feature of Akt/mTOR inhibitors is the possibility of treating advanced thyroid cancer also when resistance to single targeted therapy is conferred by multiple genetic alterations. Most of the kinase inhibitors currently under investigation are multitargeted inhibitors, with a beneficial double effect impairing the viability of tumor cells and tumor vascularization $[13,14,20,48]$. The TP53 tumor suppressor gene increases the cyclin kinase inhibitor $\mathrm{p} 21^{\text {kip1}}$, promoting cell cycle arrest at G1/S. Its inactivation by a mutation impairs the correct modulation of cell proliferation and apoptosis. This gene is mutated in $48 \%$ of ATC. The loss of the TP53 mediated control of the apoptotic machinery is probably the most difficult obstacle to overcome for a pharmacological agent to be active in ATC. Beneficial effects in ATC cell lines have been observed with an adenovirus TP53-regulated Cre/loxP system and with a E1B gene-defective adenovirus (ONYX-015) in TP53 mutant cells $[49,50]$.

\section{Conclusions}

ATC is characterized by genomic instability that leads to mutations in RET, BRAF, RAS, PTEN, PIK3CA and TP53 genes. The survival of ATC patients has changed little in the past 50 years, despite the introduction of new therapeutic tools. Given the complexity of the genomic alterations of ATC, therapy results may benefit from individualized therapeutic regimen that maximally inhibits major pathways. In the future, these therapies may be successful with a multidisciplinary approach.

\section{Competing interests}

The authors declare that they have no competing interests.

\section{Authors' contributions}

MV: conception and design, interpretation of data, AG, PZ, VDS, AG, MPC: acquisition of data, drafting the manuscript, $P Z, M V$ : critical revision, given final approval of the version to be published.

\section{Authors' information}

AG $=$ Resident in Clinical Pathology at University of Salerno VDC = Aggregate Professor of Thoracic Surgery at University of Salerno $A G=$ Aggregate Professor of Pediatric Surgery at University of Salerno $\mathrm{MC}=$ Aggregate Professor of Anatomy, University of Naples "Federico II" $C C=$ Aggregate Professor of Oncology, University of Naples "Federico II" $M T=$ Associate Professor of Endocrinology at University of Pisa $\mathrm{PZ}=$ Associate Professor of Pathology at University of Salerno $\mathrm{MV}=$ Associate Professor of Endocrinology at University of Salerno

\section{Declarations}

Funding of this project has come from personal funds.

This article has been published as part of BMC Surgery Volume 13

Supplement 2, 2013: Proceedings from the 26th National Congress of the Italian Society of Geriatric Surgery. The full contents of the supplement are available online at http://www.biomedcentral.com/bmcsurg/supplements/13/s2

\section{Authors' details}

${ }^{1}$ Medicine and Surgery, University of Salerno, Salerno, Italy. ${ }^{2}$ Public Health, University of Naples "Federico II", Naples, Italy. ${ }^{3}$ Clinical Medicine and Surgery, University of Naples "Federico II", Naples, Italy. "Endocrinology, Research Center of Excellence AmbiSEN, University of Pisa, Pisa, Italy.

Published: 8 October 2013

References

1. Soscia A, Guerra G, Cinelli MP, Testa D, Galli V, Macchi V, De Caro R: Parapharyngeal ectopic thyroid: the possible persistence of the lateral thyroid anlage. Clinical case report. Surg Radiol Anat 2004, 26(4):338-343.

2. Cooper DS, Doherty GM, Haugen BR, Kloos RT, Lee SL, Mandel SJ, Mazzaferri EL, Mclver B, Pacini F, Schlumberger M, et al: Revised American Thyroid Association management guidelines for patients with thyroid nodules and differentiated thyroid cancer. Thyroid 2009, 19(11):1167-1214.

3. Alexander EK, Kennedy GC, Baloch ZW, Cibas ES, Chudova D, Diggans J, Friedman L, Kloos RT, LiVolsi VA, Mandel SJ, et al: Preoperative diagnosis of benign thyroid nodules with indeterminate cytology. N Engl J Med 2012, 367(8):705-715.

4. Cozzolino I, Scognamiglio G, Sosa Fernandez LV, Zeppa P: Lymph nodes fine needle cytology in the diagnosis of infectious diseases: cytological and histological correlations. Infez Med 2012, 20(Suppl 3):16-20.

5. Kini SR: Thyroid Cytopathology: A Text and Atlas. Lippincott Williams \& Wilkins 2008.

6. Kim Ml, Alexander EK: Diagnostic use of molecular markers in the evaluation of thyroid nodules. Endocr Pract 2012, 18(5):796-802.

7. Cipullo C, Amato B, Vigliar E, Di Crescenzo V, Zeppa P: Lymph node fine needle cytology in the diagnosis of infectious diseases and reactive unspecific processes. Infez Med 2012, 20(Suppl 3):30-33.

8. Guerra A, Di Stasi V, Zeppa P, Faggiano A, Marotta V, Vitale M: BRAFV600E assessment by pyrosequencing in fine needle aspirates of thyroid nodules with concurrent Hashimoto's thyroiditis is a reliable assay. Endocrine 2013.

9. Illario M, Monaco S, Cavallo AL, Esposito I, Formisano P, D'Andrea L, Cipolletta E, Trimarco B, Fenzi G, Rossi G, et al: Calcium-calmodulindependent kinase II (CaMKII) mediates insulin-stimulated proliferation and glucose uptake. Cell Signal 2009, 21(5):786-792. 
10. Gervasi R, Orlando G, Lerose MA, Amato B, Docimo G, Zeppa P, Puzziello A: Thyroid surgery in geriatric patients: a literature review. BMC Surg 2012, 12(Suppl 1):S16

11. Passler C, Avanessian R, Kaczirek K, Prager G, Scheuba C, Niederle B: Thyroid surgery in the geriatric patient. Arch Surg 2002, 137(11):1243-1248.

12. Moccia F, Bonetti E, Dragoni S, Fontana J, Lodola F, Berra Romani R, Laforenza U, Rosti $V$, Tanzi F: Hematopoietic progenitor and stem cells circulate by surfing on intracellular $\mathrm{Ca} 2+$ waves: A novel target for cellbased therapy and anti-cancer treatment? Curr Signal Transd T 2012, 7(7):161-176

13. Moccia F, Dragoni S, Lodola F, Bonetti E, Bottino C, Guerra G, Laforenza U, Rosti $V$, Tanzi F: Store-dependent $\mathrm{Ca}(2+)$ entry in endothelial progenitor cells as a perspective tool to enhance cell-based therapy and adverse tumour vascularization. Curr Med Chem 2012, 19(34):5802-5818.

14. Dragoni S, Laforenza U, Bonetti E, Lodola F, Bottino C, Guerra G, Borghesi A, Stronati M, Rosti V, Tanzi F, Moccia F: Canonical Transient Receptor Potential 3 channel triggers VEGF-induced intracellular ca2+ oscillations in endothelial progenitor cells isolated from umbilical cord blood. Stem Cells and Development 2013, 22(19):2561-2580.

15. Vitale M: SEREX: a promising approach for identification of thyroid cancer serological biomarkers. Clin Endocrinol (Oxf) 2013.

16. Testa D, Guerra G, Marcuccio G, Landolfo PG, Motta G: Oxidative stress in chronic otitis media with effusion. Acta oto-laryngologica 2012, 132(8):834-837.

17. Cattaneo F, laccio A, Guerra G, Montagnani S, Ammendola R: NADPHoxidase-dependent reactive oxygen species mediate EGFR transactivation by FPRL1 in WKYMVm-stimulated human lung cancer cells. Free radical biology and medicine 2011, 51(6):1126-1136.

18. Conti V, Russomanno G, Corbi G, Guerra G, Grasso C, Filippelli W, Paribello V, Ferrara N, Filippelli A: Aerobic training workload affects human endothelial cells redox homeostasis. Medicine and science in sports and exercise 2013, 45(4):644-653.

19. Donghi R, Longoni A, Pilotti S, Michieli P, Della Porta G, Pierotti MA: Gene p53 mutations are restricted to poorly differentiated and undifferentiated carcinomas of the thyroid gland. J Clin Invest 1993, 91(4):1753-1760

20. Lodola F, Laforenza U, Bonetti E, Lim D, Dragoni S, Bottino C, Ong HL, Guerra G, Ganini C, Massa M, et al: Store-operated Ca2+ entry is remodelled and controls in vitro angiogenesis in endothelial progenitor cells isolated from tumoral patients. PLoS One 2012, 7(9):e42541.

21. Sanchez-Hernandez $Y$, Laforenza U, Bonetti E, Fontana J, Dragoni $S$, Russo M, Avelino-Cruz JE, Schinelli S, Testa D, Guerra G, et al: Storeoperated $\mathrm{Ca}(2+)$ entry is expressed in human endothelial progenitor cells. Stem Cells Dev 2010, 19(12):1967-1981.

22. Shapovalov G, Skryma R, Prevarskaya N: Calcium channels and prostate cancer. Recent Pat Anticancer Drug Discov 2013, 8(1):18-26.

23. Marotta V, Guerra A, Zatelli MC, Uberti ED, Stasi VD, Faggiano A, Colao A, Vitale M: BRAF mutation positive papillary thyroid carcinoma is less advanced when Hashimoto's thyroiditis lymphocytic infiltration is present. Clin Endocrinol (Oxf) 2013.

24. Vitale M: Rethinking the role of oncogenes in papillary thyroid cancer initiation. Front Endocrinol (Lausanne) 2012, 3:83.

25. Marotta V, Guerra A, Sapio MR, Vitale M: RET/PTC rearrangement in benign and malignant thyroid diseases: a clinical standpoint. Eur J Endocrinol 2011, 165(4):499-507.

26. Nehs MA, Nucera C, Nagarkatti SS, Sadow PM, Morales-Garcia D, Hodin RA, Parangi S: Late intervention with anti-BRAF(V600E) therapy induces tumor regression in an orthotopic mouse model of human anaplastic thyroid cancer. Endocrinology 2012, 153(2):985-994.

27. Rosove MH, Peddi PF, Glaspy JA: BRAF V600E inhibition in anaplastic thyroid cancer. N Engl J Med 2013, 368(7):684-685.

28. Zeppa P, Cozzolino I, Peluso AL, Troncone G, Lucariello A, Picardi M, Carella C, Pane F, Vetrani A, Palombini L: Cytologic, flow cytometry, and molecular assessment of lymphoid infiltrate in fine-needle cytology samples of Hashimoto thyroiditis. Cancer 2009, 117(3):174-184

29. Cozzolino I, Vigliar E, Sosa Fernandez LV, Selleri C, Pepe S, Vitale M, Triggiani M, Zeppa P: Non lymphomatous clonal B-Cell populations in enlarged lymph nodes in acquired immunodeficiency syndrome. Infez Med 2012, 20(Suppl 2):35-42.

30. Petruzziello F, Zeppa P, Ciancia G, Cozzolino I, Fernandez LS, Cervasio M, Musto P, D'Auria F, Vita G, Morabito F, et al: Cytological and histological detection of amyloid deposits in bone marrow of patients affected by multiple myeloma. Leuk Lymphoma 2011, 52(12):2304-2307.

31. Cozzolino I, Nappa S, Picardi M, De Renzo A, Troncone G, Palombini L, Zeppa $\mathrm{P}$ : Clonal B-cell population in a reactive lymph node in acquired immunodeficiency syndrome. Diagn Cytopathol 2009, 37(12):910-914.

32. Guerra A, Sapio MR, Marotta V, Campanile E, Moretti MI, Deandrea M, Motta M, Limone PP, Fenzi G, Rossi G, et al: Prevalence of RET/PTC rearrangement in benign and malignant thyroid nodules and its clinical application. Endocr J 2011, 58(1):31-38.

33. Sapio MR, Guerra A, Marotta V, Campanile E, Formisano R, Deandrea M, Motta M, Limone PP, Fenzi G, Rossi G, et al: High growth rate of benign thyroid nodules bearing RET/PTC rearrangements. J Clin Endocrinol Metab 2011, 96(6):E916-919.

34. Marotta V, Guerra A, Sapio MR, Campanile E, Motta M, Fenzi G, Rossi G, Vitale M: Growing thyroid nodules with benign histology and RET rearrangement. Endocr J 2010, 57(12):1081-1087.

35. Gupta-Abramson V, Troxel AB, Nellore A, Puttaswamy K, Redlinger M, Ransone K, Mandel SJ, Flaherty KT, Loevner LA, O'Dwyer PJ, et al: Phase II trial of sorafenib in advanced thyroid cancer. J Clin Oncol 2008, 26(29):4714-4719.

36. Xing M: Molecular pathogenesis and mechanisms of thyroid cancer. Nat Rev Cancer 2013, 13(3):184-199.

37. Guerra A, Marotta V, Deandrea M, Motta M, Limone PP, Caleo A, Zeppa P, Esposito S, Fulciniti F, Vitale M: BRAF (V600E) associates with cytoplasmatic localization of p27kip1 and higher cytokeratin 19 expression in papillary thyroid carcinoma. Endocrine 2013.

38. Chapman PB, Hauschild A, Robert C, Haanen JB, Ascierto P, Larkin J, Dummer R, Garbe C, Testori A, Maio M, et al: Improved survival with vemurafenib in melanoma with BRAF V600E mutation. $N$ Engl J Med 2011, 364(26):2507-2516.

39. Vitale M: Intratumor BRAFV600E heterogeneity and kinase inhibitors in the treatment of thyroid cancer: a call for participation. Thyroid 2013.

40. Guerra A, Fugazzola L, Marotta V, Cirillo M, Rossi S, Cirello V, Forno I, Moccia T, Budillon A, Vitale M: A high percentage of BRAFV600E alleles in papillary thyroid carcinoma predicts a poorer outcome. J Clin Endocrinol Metab 2012, 97(7):2333-2340.

41. Nazarian R, Shi H, Wang Q, Kong X, Koya RC, Lee H, Chen Z, Lee MK, Attar N, Sazegar H, et al: Melanomas acquire resistance to B-RAF(V600E) inhibition by RTK or N-RAS upregulation. Nature 2010, 468(7326): 973-977.

42. Guerra A, Sapio MR, Marotta V, Campanile E, Rossi S, Forno I, Fugazzola L, Budillon A, Moccia T, Fenzi G, et al: The Primary Occurrence of BRAFV600E Is a Rare Clonal Event in Papillary Thyroid Carcinoma. J Clin Endocrinol Metab 2012, 97(2):517-524.

43. Ricarte-Filho JC, Ryder M, Chitale DA, Rivera M, Heguy A, Ladanyi M, Janakiraman M, Solit D, Knauf JA, Tuttle RM, et al: Mutational profile of advanced primary and metastatic radioactive iodine-refractory thyroid cancers reveals distinct pathogenetic roles for BRAF, PIK3CA, and AKT1. Cancer Res 2009, 69(11):4885-4893.

44. Liu Z, Hou P, Ji M, Guan H, Studeman K, Jensen K, Vasko V, El-Naggar AK, Xing $M$ : Highly prevalent genetic alterations in receptor tyrosine kinases and phosphatidylinositol 3-kinase/akt and mitogen-activated protein kinase pathways in anaplastic and follicular thyroid cancers. J Clin Endocrinol Metab 2008, 93(8):3106-3116.

45. Hirai H, Sootome H, Nakatsuru Y, Miyama K, Taguchi S, Tsujioka K, Ueno Y, Hatch H, Majumder PK, Pan BS, et al: MK-2206, an allosteric Akt inhibitor, enhances antitumor efficacy by standard chemotherapeutic agents or molecular targeted drugs in vitro and in vivo. Mol Cancer Ther 2010, 9(7):1956-1967.

46. Liu R, Liu D, Trink E, Bojdani E, Ning G, Xing M: The Akt-specific inhibitor MK2206 selectively inhibits thyroid cancer cells harboring mutations that can activate the PI3K/Akt pathway. J Clin Endocrinol Metab 2011, 96(4):E577-585.

47. Papewalis C, Wuttke M, Schinner S, Willenberg HS, Baran AM, Scherbaum WA, Schott M: Role of the novel mTOR inhibitor RAD001 (everolimus) in anaplastic thyroid cancer. Horm Metab Res 2009, 41(10):752-756.

48. Marotta V, Franzese MD, Del Prete M, Chiofalo MG, Ramundo V, Esposito R, Marciello F, Pezzullo L, Carratu A, Vitale M, et al: Targeted therapy with kinase inhibitors in aggressive endocrine tumors. Expert Opin Pharmacother 2013, 14(9):1187-1203. 
49. Nagayama $Y$, Nishihara E, Namba H, Yokoi H, Hasegawa M, Mizuguchi H, Hayakawa T, Hamada H, Yamashita S, Niwa M: Targeting the replication of adenovirus to p53-defective thyroid carcinoma with a p53-regulated Cre/loxP system. Cancer Gene Ther 2001, 8(1):36-44.

50. Portella G, Scala S, Vitagliano D, Vecchio G, Fusco A: ONYX-015, an E1B gene-defective adenovirus, induces cell death in human anaplastic thyroid carcinoma cell lines. J Clin Endocrinol Metab 2002, 87(6):2525-2531.

51. Fukushima T, Suzuki S, Mashiko M, Ohtake T, Endo Y, Takebayashi Y, Sekikawa K, Hagiwara K, Takenoshita S: BRAF mutations in papillary carcinomas of the thyroid. Oncogene 2003, 22(41):6455-6457.

52. Namba H, Nakashima M, Hayashi T, Hayashida N, Maeda S, Rogounovitch TI, Ohtsuru A, Saenko VA, Kanematsu T, Yamashita S: Clinical implication of hot spot BRAF mutation, V599E, in papillary thyroid cancers. J Clin Endocrinol Metab 2003, 88(9):4393-4397.

53. Nikiforova MN, Kimura ET, Gandhi M, Biddinger PW, Knauf JA, Basolo F, Zhu Z, Giannini R, Salvatore G, Fusco A, et al: BRAF mutations in thyroid tumors are restricted to papillary carcinomas and anaplastic or poorly differentiated carcinomas arising from papillary carcinomas. J Clin Endocrinol Metab 2003, 88(11):5399-5404.

54. Xing M, Vasko V, Tallini G, Larin A, Wu G, Udelsman R, Ringel MD, Ladenson PW, Sidransky D: BRAF T1796A transversion mutation in various thyroid neoplasms. J Clin Endocrinol Metab 2004, 89(3):1365-1368.

55. Begum S, Rosenbaum E, Henrique R, Cohen Y, Sidransky D, Westra WH: BRAF mutations in anaplastic thyroid carcinoma: implications for tumor origin, diagnosis and treatment. Mod Pathol 2004, 17(11):1359-1363.

56. Fugazzola L, Mannavola D, Cirello V, Vannucchi G, Muzza M, Vicentini L, Beck-Peccoz P: BRAF mutations in an Italian cohort of thyroid cancers. Clin Endocrinol (Oxf) 2004, 61(2):239-243.

57. Soares P, Trovisco V, Rocha AS, Feijao T, Rebocho AP, Fonseca E, Vieira de Castro I, Cameselle-Teijeiro J, Cardoso-Oliveira M, Sobrinho-Simoes M: BRAF mutations typical of papillary thyroid carcinoma are more frequently detected in undifferentiated than in insular and insular-like poorly differentiated carcinomas. Virchows Arch 2004, 444(6):572-576.

58. Santarpia L, El-Naggar AK, Cote GJ, Myers JN, Sherman SI: Phosphatidylinositol 3-kinase/akt and ras/raf-mitogen-activated protein kinase pathway mutations in anaplastic thyroid cancer. J Clin Endocrinol Metab 2008, 93(1):278-284.

59. Manenti G, Pilotti S, Re FC, Della Porta G, Pierotti MA: Selective activation of ras oncogenes in follicular and undifferentiated thyroid carcinomas. Eur J Cancer 1994, 30A(7):987-993.

60. Garcia-Rostan G, Zhao H, Camp RL, Pollan M, Herrero A, Pardo J, Wu R, Carcangiu ML, Costa J, Tallini G: ras mutations are associated with aggressive tumor phenotypes and poor prognosis in thyroid cancer. $J$ Clin Oncol 2003, 21(17):3226-3235.

61. Hou P, Liu D, Shan Y, Hu S, Studeman K, Condouris S, Wang Y, Trink A, ElNaggar AK, Tallini G, et al: Genetic alterations and their relationship in the phosphatidylinositol 3-kinase/Akt pathway in thyroid cancer. Clin Cancer Res 2007, 13(4):1161-1170.

62. Basolo F, Pisaturo F, Pollina LE, Fontanini G, Elisei R, Molinaro E, lacconi P, Miccoli $\mathrm{P}$, Pacini $\mathrm{F}$ : N-ras mutation in poorly differentiated thyroid carcinomas: correlation with bone metastases and inverse correlation to thyroglobulin expression. Thyroid 2000, 10(1):19-23.

63. Mochizuki K, Kondo T, Nakazawa T, Iwashina M, Kawasaki T, Nakamura N, Yamane T, Murata S, Ito K, Kameyama K, et al: RET rearrangements and BRAF mutation in undifferentiated thyroid carcinomas having papillary carcinoma components. Histopathology 2010, 57(3):444-450.

64. Tallini G, Santoro M, Helie M, Carlomagno F, Salvatore G, Chiappetta G, Carcangiu ML, Fusco A: RET/PTC oncogene activation defines a subset of papillary thyroid carcinomas lacking evidence of progression to poorly differentiated or undifferentiated tumor phenotypes. Clin Cancer Res 1998, 4(2):287-294.

65. Dahia PL, Marsh DJ, Zheng Z, Zedenius J, Komminoth P, Frisk T, Wallin G, Parsons $\mathrm{R}$, Longy $M$, Larsson $C$, et al: Somatic deletions and mutations in the Cowden disease gene, PTEN, in sporadic thyroid tumors. Cancer Res 1997, 57(21):4710-4713.

66. Garcia-Rostan G, Costa AM, Pereira-Castro I, Salvatore G, Hernandez R, Hermsem MJ, Herrero A, Fusco A, Cameselle-Teijeiro J, Santoro M: Mutation of the PIK3CA gene in anaplastic thyroid cancer. Cancer Res 2005, 65(22):10199-10207.
67. Fagin JA, Matsuo K, Karmakar A, Chen DL, Tang SH, Koeffler HP: High prevalence of mutations of the p53 gene in poorly differentiated human thyroid carcinomas. J Clin Invest 1993, 91(1):179-184.

68. Ito T, Seyama T, Mizuno T, Tsuyama N, Hayashi T, Hayashi Y, Dohi K, Nakamura N, Akiyama M: Unique association of p53 mutations with undifferentiated but not with differentiated carcinomas of the thyroid gland. Cancer Res 1992, 52(5):1369-1371.

doi:10.1186/1471-2482-13-S2-S44

Cite this article as: Guerra et al:: Genetic mutations in the treatment of anaplastic thyroid cancer: a systematic review. BMC Surgery 201313 (Suppl 2):S44.

\section{Submit your next manuscript to BioMed Central and take full advantage of:}

- Convenient online submission

- Thorough peer review

- No space constraints or color figure charges

- Immediate publication on acceptance

- Inclusion in PubMed, CAS, Scopus and Google Scholar

- Research which is freely available for redistribution

Submit your manuscript at www.biomedcentral.com/submit
C Biomed Central 